\title{
The effect of protein deficiency and calorie deficiency on the reproduction of rats
}

\author{
By ELSIE M. WIDDOWSON AND JEAN COWEN \\ Dunn Nutritional Laboratory, Infant Nutrition Research Division, \\ University of Cambridge and Medical Research Council
}

(Received I 2 fanuary 1971 - Accepted 30 fuly I97I)

\begin{abstract}
I. Groups of twelve female rats were fed from 4 weeks of age on four different experimental dietary regimens, and on a stock diet containing $18 \%$ protein given ad lib. as a control (group I). The rats in two of the experimental groups were malnourished either by being given a lowprotein $(9 \%$ ) diet ad lib. (group 2), or the stock diet containing $18 \%$ protein in limited amounts to maintain weight as in group 2. These animals were designated calorie-deficient (group 3). Two other groups of twelve rats were more severely malnourished from 4 to 13 weeks of age by being given a low-protein (6\%) diet $\alpha d$ lib. (group 4 ) or the stock diet in limited amounts to maintain weight as in group 4 (group 5 ). From 13 weeks all the rats in groups 4 and 5 were rehabilitated on stock diet ad lib.

2. Well-nourished males were introduced into the cages $\mathbf{x}$ week after the vaginas opened, and again immediately after the females had suckled successive litters. This was repeated until the females were 60 weeks old and had reared up to six litters.

3. Chronic deprivation of protcin or of calories delayed puberty, reduccd fertility and gave rise to smaller numbers in the litters. It also interfered with lactation.

4. More severe malnutrition for 9 weeks further delayed puberty, but when these animals were rehabilitated they produced as many young as those that had been well-nourished throughout. They lactated well and there was no carry-over of the effects of the early deficiencies.
\end{abstract}

This investigation was inspired by a telephone call from a colleague. He was concerned about the population explosion and wondered to what extent malnutrition or its relief might affect it. Had any long-term studies been made on animals to find out what the effect of a lifetime of malnutrition on their reproductive performance might be? A search of the literature showed that some work had been done on this subject with rats. Most investigators, however, imposed the malnutrition only after the animals had mated successfully and were, therefore, presumably pregnant. Some then restricted the quantity of food without altering its quality (Chow, I964; Chow 8 Lee, I964; Berg, I965; Lee \& Chow, 1965), whereas others allowed the pregnant animals free access to a diet containing too small a percentage of protein (Seegers, 1937; Nelson \& Evans, I953; Curtiss, I953; Richardson, Godwin, Wilkes \& Cannon, 1964; Venkatachalam \& Ramanathan, 1964; Zeman, 1967). All agreed that either of these forms of malnutrition, if sufficiently severe, led to a reduction in the number in the litter, and to a small size of the young at birth. Such animals continued to grow more slowly than normal animals after birth, even if they were suckled by wellnourished females. Stewart \& Sheppard (I97I) have recently examined the reproductive performance of female rats after their first mating, these females having themselves been fed since weaning on diets with protein values of NDpCal $\%=$ ro or 5 . Their results are similar to those of other workers.

None of these investigations answered all the questions that had been posed, and 
it was therefore decided to design experiments that might do so. The questions were: what is the effect on the reproductive performance of animals of (I) a deficiency of calories or of protein imposed early in life and maintained thereafter and (2) a more severe deficiency of calories or of protein early in life but followed by rehabilitation on an adequate diet?

\section{MATERIALS AND METHODS}

Sixty female rats of the black and white hooded Lister strain were used for this experiment. They came from seventeen litters, and were suckled along with males to make up the numbers to eight until they were 3 weeks old, and then allowed free access to the stock diet (diet 4I B; Bruce, 1957) until they were 4 weeks old. They were then divided into five groups of twelve, all twelve in each group coming from different litters. Each litter was represented in at least two of the groups, and in four instances in all five of them. The mean weight of the animals in each group was between $49^{\cdot 6}$ and $50^{\circ} \circ \mathrm{g}$. Those in group I were the well-nourished controls and they were allowed unlimited amounts of the stock diet, which contained i $8 \%$ protein. Those in groups 2 and 3 were malnourished from 4 weeks onwards. The animals in group 2 had free access to a diet containing $9 \%$ protein, made up by diluting the stock diet with sugar and adding mixtures of vitamins and minerals as described by Baird, Widdowson \& Cowley (197I); these protein-deficient animals did not take as much food or gain as much weight as those in group $\mathrm{I}$. The rats in group 3 were given the stock diet in limited amounts so that the mean weight remained as near as possible to that of the protein-deficient animals in group 2 , though this was not achieved very exactly. They were designated 'calorie-deficient'. The rats in group 4 were given unlimited amounts of a diet containing only $6 \%$ protein from 4 to $\mathrm{r}_{3}$ weeks of age, and those in group 5 just enough of the stock diet to enable them to gain weight at approximately the same slow rate as the rats in group 4 till they were 13 weeks old. All the severely proteindeficient and calorie-deficient rats in groups 4 and 5 were rehabilitated from 13 weeks by being given the stock diet $a d l i b$. for the rest of the experiment.

The date on which each rat's vagina opened was noted and the animal was then weighed. From about $\mathrm{r}$ week later a normal male rat was put into each cage of six females in groups 1,2 and 3 every evening at 17.00 hours and removed at 09.00 hours and this continued until all the females became pregnant. The males were allowed the stock diet ad lib. during the day-time. The male was first introduced to the cages of females in groups 4 and 5 one week after rehabilitation had begun. Before delivery all the females were put into small breeding cages by themselves with wood-wool as nesting material. Litters were weighed and counted at birth, the number was reduced to 8 by removing animals at random, and the mother herself weighed after delivery of her litter. She was allowed to suckle her litter for 3 weeks and the litters were weighed weekly. When the young were removed at 3 weeks the mothers were weighed and put back into the larger cages and a male was introduced each night as before and this whole procedure repeated until all the rats were 60 weeks old.

The males from the fifth litters of the well-nourished mothers and from the fourth litters in the other four groups were reared on the stock pelleted diet from 3 weeks and were weighed at weekly intervals until they were 29 weeks old. 


\section{RESULTS}

\section{The mothers}

Table I shows the mean age of the rats in the five groups when the vagina opened. Both deficiencies delayed the opening, and the more severe the deprivation the more the delay. Table I also shows the mean weight of the animals when the vagina opened. The severely calorie-deficient animals (group 5) weighed significantly less than the well-nourished controls $(P<0.001)$ and than the severely protein-deficient animals in group $4(0.005>P>0.00 \mathrm{I})$. There was no significant difference between the weights of the protein-deficient rats and the controls.

Table I. Opening of the vagina in well-nourished and malnourished rats

(Mean values with their standard deviations for groups of twelve rats)

Treatment group

(I) Well-nourished

Malnourished 4 weeks old onwards

(2) Protein-deficient

(3) Calorie-deficient

Severely malnourished

(4) Protein-deficient
(5) Calorie-deficient
Age

(d)

$$
39 \cdot 6 \pm 2 \cdot 8
$$

$56 \cdot 8 \pm 8 \cdot 0$

$55^{\cdot} 8 \pm 9^{\circ}$ I

$4^{-13}$ weeks, then rehabilitated
Weight

(g)

$$
88 \cdot 8 \pm 10 \cdot 4
$$

$$
\begin{aligned}
& 96 \cdot 9 \pm 16 \cdot 8 \\
& 77 \cdot 3 \pm 13 \cdot 2
\end{aligned}
$$

$86 \cdot 0 \pm \mathbf{2 2} \cdot 8$ $62 \cdot 8 \pm 8 \cdot 3$

Table 2. Numbers of rats delivering and rearing successive litters (Twelve females in each group)

$$
\begin{aligned}
& \text { Total no. of } \\
& \text { litters de- } \\
& \text { livered and } \\
& \text { reared by } \\
& \text { I2 rats up } \\
& \text { to } 60 \text { weeks } \\
& \text { of age }
\end{aligned}
$$

(I) Well-nourished Delivered Reared

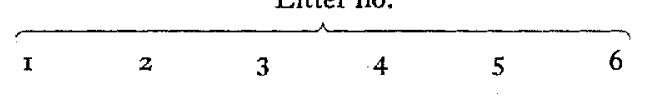

$\begin{array}{rrrrrr}12 & \text { I2 } & 12 & \text { 10 } & \text { 10 } & 7 \\ 12 & 12 & 12 & 9 & 9 & 7\end{array}$

6I

Malnourished 4 weeks onwards

(2) Protein-deficient

Delivered Reared

$\begin{array}{lrrrrr}12 & 10 & 9 & 7 & - & - \\ 12 & 9 & 8 & 5 & - & - \\ 12 & \text { I2 } & 10 & 10 & 2 & - \\ 12 & 12 & 9 & 10 & 2 & -\end{array}$

(3) Calorie-deficient Delivered

9

Severely malnourished $4^{-13}$ weeks then rehabilitated

(4) Protein-deficient

Delivered
Reared
5) Calorie-deficient
Delivered
Reared

II 10 10

$12 \quad 12$

$12 x_{2}$

* Eleven mothers only; for twelve mothers value would be 58 . 
Table 3. Total numbers of young produced by the twelve well-nourished or malnourished rats in each group over the 60 weeks of the experiment

Treatment group

(I) Well-nourished

692

Malnourished 4 weeks onwards

(2) Protein-deficient 288

(3) Calorie-deficient 395

Severely malnourished $4-13$ weeks and rehabilitated
(4) Protein-deficient* 598

(5) Calorie-deficient 740

* Eleven mothers only; for twelve mothers the total would be 652 .

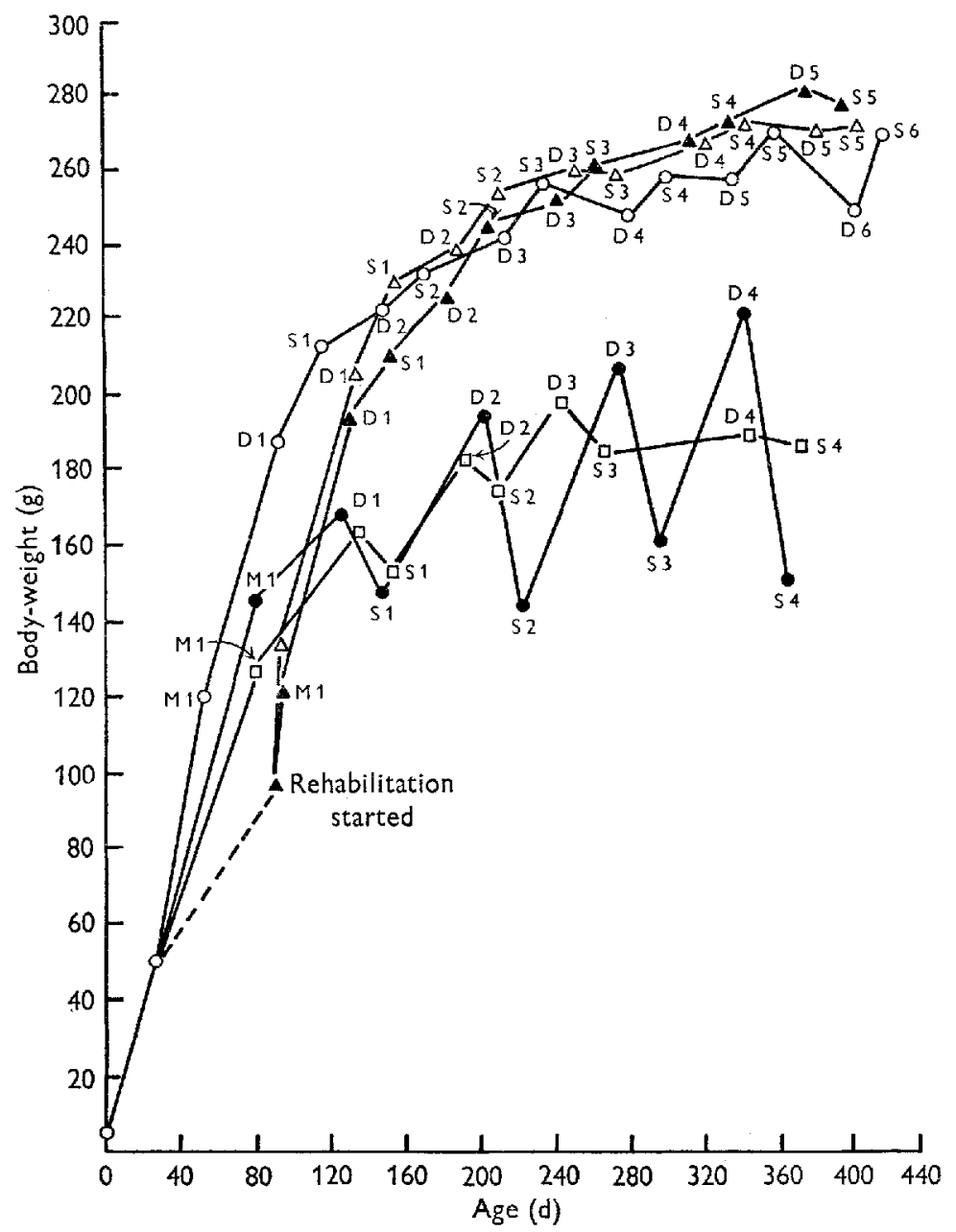

Fig. I. Mean weights of female rats at successive stages of the experiment. $O$, group r, wellnourished; $\bigcirc$, group 2, protein-deficient; $\square$, group 3 , calorie-deficient; $\triangle$, group 4, proteindeficient then rehabilitated; $\boldsymbol{\Delta}$, group 5, caloric-deficient then rehabilitated. M, mated; $D$, delivered; $\mathrm{S}$, suckling completed. 
Table 2 shows how many of the twelve females in each group produced and reared their first, second, third, fourth, fifth and sixth litters by the time they were 60 weeks old. One rat in group 4 died during the period of malnutrition so only eleven animals were available for study. All twelve well-nourished rats reared three litters and so did the rehabilitated calorie-deficient ones (group 5). The calorie-deficient rats (group 3) made a better showing than the corresponding protein-deficient animals (group 2), and those that had been severely undernourished and then rehabilitated (group 5) reared only one less litter in all than those that had been well-nourished throughout even though their reproductive life began later and they were 4 weeks older when their first litters were born.

Table 4. Days after male rat introduced into cage before litter was delivered

\begin{tabular}{|c|c|c|c|c|c|c|}
\hline \multicolumn{7}{|c|}{ (Median and range) } \\
\hline Treatment group & I & 2 & 3 & 4 & 5 & 6 \\
\hline (I) Well-nourished & $\begin{array}{c}3^{8} \\
\left(33^{-66)}\right.\end{array}$ & $\begin{array}{c}26 \\
(23-47)\end{array}$ & $\begin{array}{c}32 \\
\left(23^{-1} 18\right)\end{array}$ & $\begin{array}{c}33 \\
(28-77)\end{array}$ & $\begin{array}{c}3 t \\
(24-72)\end{array}$ & $\begin{array}{c}33 \\
(24-84)\end{array}$ \\
\hline $\begin{array}{l}\text { Malnourished } 4 \text { weeks } \\
\text { (2) Protein-deficient }\end{array}$ & $\begin{array}{l}\text { ds } \\
32 \\
(21-152)\end{array}$ & $\begin{array}{c}39 \\
(25-8 I)\end{array}$ & $\begin{array}{c}51 \\
(25-84)\end{array}$ & $\begin{array}{c}29 \\
(22-6 I)\end{array}$ & - & - \\
\hline (3) Calorie-deficient & $\stackrel{33}{(27-96)}$ & $\begin{array}{c}33 \\
\left(23^{-12 I}\right)\end{array}$ & $\begin{array}{c}28 \\
(23-48)\end{array}$ & $\begin{array}{c}64 \\
(22-88)\end{array}$ & $\begin{array}{c}27 \\
(24,29)\end{array}$ & 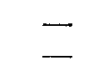 \\
\hline $\begin{array}{l}\text { Severely malnourished } \\
\text { (4) Protein-deficient }\end{array}$ & $\begin{array}{c}\text { weeks and } \\
30 \\
\left(23^{-55}\right)\end{array}$ & $\begin{array}{l}\text { ehabilitate } \\
24 \\
(22-53)\end{array}$ & $\begin{array}{c}31 \\
(23-55)\end{array}$ & $\begin{array}{c}44 \\
(28-100)\end{array}$ & $\begin{array}{c}3 I \\
(23-95)\end{array}$ & $\begin{array}{c}30 \\
(29,3 x)\end{array}$ \\
\hline (5) Calorie-deficient & $\begin{array}{c}31 \\
\left(23^{-77}\right)\end{array}$ & $\begin{array}{c}26 \\
(23-47)\end{array}$ & $\begin{array}{c}35 \\
(25-96)\end{array}$ & $\begin{array}{c}3^{8} \\
(26-65)\end{array}$ & $\begin{array}{c}30 \\
\left(23^{-54}\right)\end{array}$ & $\begin{array}{c}4 \mathbf{I} \\
(27-66)\end{array}$ \\
\hline
\end{tabular}

Table 3 shows the total number of young produced by the twelve mothers in each group up to the time they were 60 weeks old. The twelve mothers which had been severely undernourished for 9 weeks and then rehabilitated between them produced 740 young, which was more than the twelve control mothers which had never been malnourished at all. The rehabilitated protein-deficient mothers did not do quite so well, and those that were chronically malnourished had only about half as many young.

Fig. I shows the weights of the female rats at successive stages of the experiment. The well-nourished rats produced their first litters when they were $94 \mathrm{~d}$ old and were still rapidly growing. Pregnancy and lactation did not appear to interfere with growth, and it was not until the second pregnancy that there was a break in the growth curve. The rats recovered weight during lactation, and this sequence continued, becoming more and more marked with successive litters. Both groups of animals severely malnourished from 4 to 13 weeks of age and then rehabilitated also produced and reared their first litters without any serious setback to their gain in weight. They were older and a little heavier than the control animals when this occurred. They caught up with the controls in weight and passed them and, although they also showed a tendency to change less in weight during pregnancy and gain more during lactation, this did not invariably happen. 
The rats that were living on a diet containing $9 \%$ protein (group 2) weighed less than the control or rehabilitated animals when they delivered their first litters, and they were lighter at each stage thereafter. Lactation was to them a greater stress than pregnancy, and during each lactation they lost a great deal of body substance - up to $32 \%$ of their weight - but they more than regained this during the next pregnancy.

'The rats that were chronically short of calories (group 3) also weighed less than the control or rehabilitated animals. Their mean weight at each stage was of the same order as that of the animals in group 2, but they became pregnant for the second time sooner than those in group 2, so from then onwards they could not be matched in weight with them. The big loss in weight of the group 2 animals during their later lactations was not foreseen, and the calorie-deficient animals in group 3 were in fact heavier at the end of their second, third and fourth lactations than the protein-deficient animals in group 2.

'Table 4 shows the number of days that elapsed between the first introduction of the male into the cage and the birth of the litter. The values were so variable that the median and range are given rather than the mean. The information must be considered along with that given in Table 2, for it only applies to those females that had litters and, as Table 2 shows, many of the animals did not produce fifth and sixth litters at all. The long interval before the well-nourished controls had their first litters is probably explained by their small size and young age. The quickest mating for all the animals having stock diet ad lib. (groups I, 4, 5) occurred before the second litters. It is evident that the animals that had been malnourished and then rehabilitated were as fertile as those that had been well-nourished all their lives.

\section{The young at birth}

Table 5 shows the mean numbers of young born and the range. Again, the values apply only to mothers that had litters; those that failed to produce litters have been excluded. On the whole, second litters were the largest. Mothers that had been severely

Table 5. Numbers of young born to well-nourished and malnourished rats

\begin{tabular}{|c|c|c|c|c|c|c|}
\hline \multicolumn{7}{|c|}{$\begin{array}{l}\text { (Mean and range) } \\
\text { Litter } n\end{array}$} \\
\hline Treatment group & $I$ & 2 & 3 & 4 & 5 & 6 \\
\hline (I) Well-nourished & $\begin{array}{c}10 \cdot 8 \\
(5-16)\end{array}$ & $\begin{array}{c}13 \cdot 8 \\
(12-18)\end{array}$ & $\begin{array}{c}\text { I2*I } \\
\left(3^{-18}\right)\end{array}$ & $\begin{array}{c}10 \cdot 4 \\
(5-13)\end{array}$ & $\begin{array}{c}9 \cdot 9 \\
(7-13)\end{array}$ & $\begin{array}{c}9 \cdot 7 \\
(3-14)\end{array}$ \\
\hline \multicolumn{7}{|c|}{ Malnourished 4 weeks onwards } \\
\hline (2) Protein-deficient & $\begin{array}{c}8 \cdot 1 \\
(3-12)\end{array}$ & $\begin{array}{c}8 \cdot 9 \\
(6-12)\end{array}$ & $\begin{array}{c}8 \cdot 3 \\
(2-11)\end{array}$ & $\begin{array}{c}7 \cdot 2 \\
(4-10)\end{array}$ & - & - \\
\hline (3) Calorie-deficient & $\begin{array}{c}9 \cdot 0 \\
(8-11)\end{array}$ & $\begin{array}{c}9 \cdot 8 \\
(5-13)\end{array}$ & $\begin{array}{c}8 \cdot 3 \\
(4-14)\end{array}$ & $\begin{array}{c}7 \cdot 2 \\
(7-11)\end{array}$ & $\stackrel{\text { I I }}{(10,12)}$ & - \\
\hline \multicolumn{7}{|c|}{ Severely malnourished $4-13$ weeks and rehabilitated } \\
\hline (4) Protein-deficient & $\begin{array}{c}\text { II } \cdot 2 \\
(8-15)\end{array}$ & $\begin{array}{l}12 \cdot 0 \\
(7-14)\end{array}$ & $\begin{array}{c}\mathrm{I} 2 \cdot 0 \\
(8-16)\end{array}$ & $\begin{array}{c}\text { I } 2 \cdot 8 \\
(5-19)\end{array}$ & $\begin{array}{l}10 \cdot 3 \\
\left(5^{-14}\right)\end{array}$ & $\begin{array}{l}7 \cdot 0 \\
(5,9)\end{array}$ \\
\hline (5) Calorie-deficient & $\begin{array}{c}12 \cdot 6 \\
(8-15)\end{array}$ & $\begin{array}{c}13 \cdot 2 \\
(8-16)\end{array}$ & $\begin{array}{c}\text { II } 6 \\
(3-x 7)\end{array}$ & $\begin{array}{c}13.1 \\
(5-18)\end{array}$ & $\begin{array}{c}13.0 \\
(10-15)\end{array}$ & $\begin{array}{c}7 \cdot 5 \\
(6-13)\end{array}$ \\
\hline
\end{tabular}


malnourished and then rehabilitated produced as many young in each successive litter as the well-nourished controls, but chronic deprivation of either protein or calories reduced the number of young reaching full term. Whether this was because fewer were conceived or some foetuses were resorbed in utero is not known.

\section{Table 6. Total weight $(g)$ at birth of litters born to well-nourished and malnourished rats}

(Mean values and standard deviations)

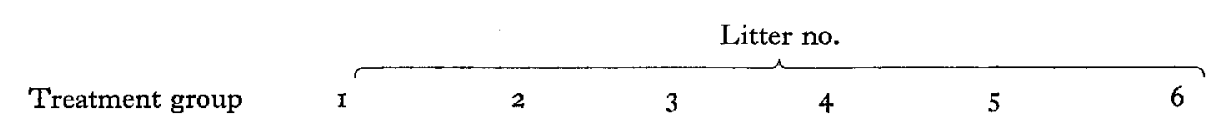

(I) Well-nourished

$55 \cdot 3 \pm 13 \cdot 6 \quad 69 \cdot 6 \pm 9 \cdot 35 \quad 62 \cdot 5 \pm 17 \cdot 8 \quad 47 \cdot 8 \pm 12 \cdot 4 \quad 49 \cdot 6 \pm 8 \cdot 27 \quad 51 \cdot 3 \pm 21 \cdot 4$

Malnourished 4 weeks onwards

$\begin{array}{lllllll}\text { (2) Protein-deficient } & 39.5 \pm 14.5 & 42.4 \pm 9.57 & 33.1 \pm 18.6 & 34.3 \pm 10.7 & - & \text { - } \\ \text { (3) Calorie-deficient } & 45.9 \pm 9.92 & 46.3 \pm 8.41 & 36.1 \pm 10.0 & 44.2 \pm 6.46 & 53.5\left(57^{\circ} 0,50^{\circ} 0\right) & \text { - }\end{array}$

Severely malnourished $4-13$ weeks and rehabilitated

(4) Protein-deficient $57 \cdot 4 \pm$ II'I $\quad 57 \cdot 3 \pm 9 \cdot 43 \quad 63 \cdot 2 \pm$ II I I $\quad 62 \cdot 4 \pm 21 \cdot 3 \quad 54 \cdot 2 \pm$ I $5 \cdot 6 \quad 35 \cdot 5(45 \cdot 0,26 \cdot 0)$

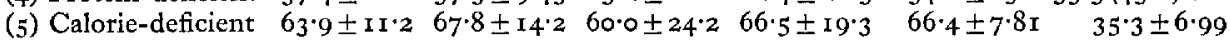

Table 7. Mean birth weights $(g)$ of individual young in successive litters born to well-nourished and malnourished rats

(Mean values and standard deviations)

Litter no.

Treatment group

\begin{tabular}{cccccc}
\hline I & 2 & 3 & 4 & 5 & 6 \\
5.15 & 5.08 & 5.21 & 4.73 & 5.12 & 3.33 \\
\pm 0.390 & \pm 0.698 & \pm 0.399 & \pm 0.862 & \pm 0.523 & \pm 0.430
\end{tabular}

Malnourished 4 weeks onwards

$\begin{array}{lcccccc}\text { (2) Protein-deficient } & 5.14 & 4.77 & 4.68 & 4.56 & - & - \\ & \pm 0.92 & \pm 0.41 & \pm 0.89 & \pm 0.83 & - & - \\ \text { (3) Calorie-deficient } & 5.07 & 4.79 & 5.48 & 4.82 & 4.88 & - \\ & \pm 0.701 & \pm 0.534 & \pm 0.749 & \pm 0.534 & 4.75,5.00 & -\end{array}$

Severely malnourished $4^{-1} 3$ weeks and rehabilitated

$\begin{array}{lcccccc}\text { (4) Protein-deficient } & 5.14 & 4.85 & 5.29 & 4.79 & 5.28 & 5.4 \mathrm{r} \\ & \pm 0.60 & \pm 0.74 & \pm 0.41 & \pm 0.67 & \pm 0.31 & 5.62,5.20 \\ \text { (5) Calorie-deficient } & 5.07 & 5.17 & 5.12 & 5.06 & 5.13 & 4.68 \\ & \pm 0.34 & \pm 0.50 & \pm 1.00 & \pm 0.22 & \pm 0.33 & \pm 0.40\end{array}$

Table 6 shows the total weights of the litters at birth, and Table 7 the mean weight of the individual young. In most instances the second litters weighed the most; this was because the number in the litter was the greatest, not because eac $h$ individual weighed more. The total weights of the young produced by the malnourished animals (groups 2 and 3 ) were less than those of the young produced by the well-nourished rats, or of those whose mothers had been deprived early in life and then rehabilitated. Again, the difference in number was a more important reason than difference in size of each individual young. For each of the first four litters the total weight of the young at birth was lower for the rats having the diet containing $9 \%$ protein (group 2) than 
for the calorie-deficient animals (group 3 ) but the differences were not statistically significant. The rehabilitated calorie-deficient animals (group 5) produced a particularly large weight of young.

\section{The young at 3 weeks}

Table 8 shows the weights of the individual young at 3 weeks of age, and therefore gives a measure of the ability to lactate of those mothers that produced and reared their litters. Eight were given to each mother to suckle. The mothers that had

Table 8. Mean weights ( $g$ ) at 3 weeks of individual young in successive litters born to well-nourished and malnourished rats

(Mean values and standard deviations)

\begin{tabular}{|c|c|c|c|c|c|c|}
\hline \multirow[b]{2}{*}{ Treatment group } & \multicolumn{6}{|c|}{ Litter no. } \\
\hline & I & 2 & 3 & 4 & 5 & 6 \\
\hline (I) Well-nourished & $\begin{array}{l}31 \cdot 0 \\
\pm 3 \cdot 9 \mathrm{I} \\
(7 \cdot 7)\end{array}$ & $\begin{array}{c}3 \mathrm{I} \cdot 9 \\
\pm 3 \cdot 3 \mathrm{I} \\
(7 \cdot 8)\end{array}$ & $\begin{array}{c}34 \cdot 7 \\
\pm 3 \cdot 93 \\
(7 \cdot 3)\end{array}$ & $\begin{array}{c}35 \cdot 0 \\
+6 \cdot 18 \\
(7 \cdot 4)\end{array}$ & $\begin{array}{c}34 \cdot 9 \\
\pm 2 \cdot 91 \\
(7 \cdot 3)\end{array}$ & $\begin{array}{c}33 \cdot 3 \\
\pm 4 \cdot 66 \\
(6 \cdot 4)\end{array}$ \\
\hline $\begin{array}{l}\text { Malnourished } 4 \text { weeks } \\
\text { (2) Protein-deficient }\end{array}$ & $\begin{array}{l}\text { ards } \\
18.5 \\
\pm 8.81 \\
(6 \cdot 3)\end{array}$ & $\begin{array}{l}13 \cdot 2 \\
\pm x \cdot 26 \\
(7 \cdot I)\end{array}$ & $\begin{array}{c}15 \cdot 3 \\
\pm 6 \cdot 11 \\
(5 \cdot 6)\end{array}$ & $\begin{array}{l}I 2 \cdot 3 \\
\pm 2 \cdot 21 \\
(6 \cdot 6)\end{array}$ & E & 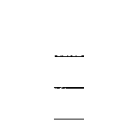 \\
\hline (3) Calorie-deficient & $\begin{array}{c}22 \cdot 8 \\
\pm 2 \cdot 85 \\
(7 \cdot 8)\end{array}$ & $\begin{array}{l}26 \cdot 1 \\
\pm 3 \cdot 47 \\
(7 \cdot 7)\end{array}$ & $\begin{array}{l}32 \cdot 3 \\
\pm 7 \cdot 95 \\
(7 \cdot 6)\end{array}$ & $\begin{array}{c}26 \cdot 9 \\
\pm 2 \cdot 03 \\
(7 \cdot 6)\end{array}$ & $\begin{array}{c}28 \cdot 2 \\
24 \cdot 0,32 \cdot 4 \\
(7 \cdot 5)\end{array}$ & - \\
\hline $\begin{array}{l}\text { Severely malnourished } \\
\text { (4) Protein-deficient }\end{array}$ & $\begin{array}{c}3 \text { weeks } \\
29 \cdot 6 \\
\pm 5.88 \\
(8 \cdot 0)\end{array}$ & $\begin{array}{c}\text { rehabilit } \\
30.8 \\
\pm 4.7 \mathbf{I} \\
(7 \cdot 4)\end{array}$ & $\begin{array}{c}31.4 \\
\pm 3.77 \\
(7 \cdot 5)\end{array}$ & $\begin{array}{c}33.4 \\
\pm 3.09 \\
(7 \cdot 7)\end{array}$ & $\begin{array}{c}36 \cdot 7 \\
\pm 8 \cdot 43 \\
(6 \cdot 3)\end{array}$ & $\begin{array}{c}40 \cdot 6 \\
30 \cdot \mathrm{I}, 5 \mathrm{I} \cdot \mathrm{C} \\
(5 \cdot 0)\end{array}$ \\
\hline (5) Calorie-deficient & $\begin{array}{c}35.2 \\
\pm 4.20 \\
(8.0)\end{array}$ & $\begin{array}{l}35.0 \\
\pm 3.80 \\
(7.8)\end{array}$ & $\begin{array}{c}33 \cdot 7 \\
+8 \cdot 62 \\
(6 \cdot 4)\end{array}$ & $\begin{array}{c}37 \cdot 0 \\
\pm 3 \cdot 12 \\
(7 \cdot 3)\end{array}$ & $\begin{array}{c}38 \cdot 2 \\
\pm 3 \cdot 25 \\
(6 \cdot 8)\end{array}$ & $\begin{array}{c}36 \cdot 3 \\
\pm 3 \cdot 84 \\
(6 \cdot 0)\end{array}$ \\
\hline
\end{tabular}

Values in parentheses are the average numbers of young rats (eight were given to each mother to suckle) reared to 3 weeks.

been severely deprived of calories and then rehabilitated (group 5) produced just as much milk as the well-nourished controls. The young of the corresponding previously protein-deficient animals (group 4 ) were in no instance quite as large as the young of mothers that had been calorie-deficient. The chronically calorie-deficient rats (group 3) lactated well after their first lactation, and this contrasts with the lactation of the protein-deficient animals of similar body-weight after delivery (group 2). Their young were always very small.

\section{Subsequent growth of male offspring}

The subsequent growth of the male rats in the fourth and fifth litters is shown in Fig. 2. The numbers in each group are indicated in the legend to the figure. The weight of these rats at all stages was influenced by their weight at weaning. Those from the chronically protein-deficient mothers, whose average weight was only onehalf to one-third as much as others, grew more slowly at the outset and became 
smaller adults than those that were larger and, in fact, the mean weight of the groups at 29 weeks was in almost the same order as it was at 3 weeks, the only difference being that the young of the well-nourished controls had caught up with and overtaken the young of the rehabilitated calorie-deficient animals by ro weeks of age.

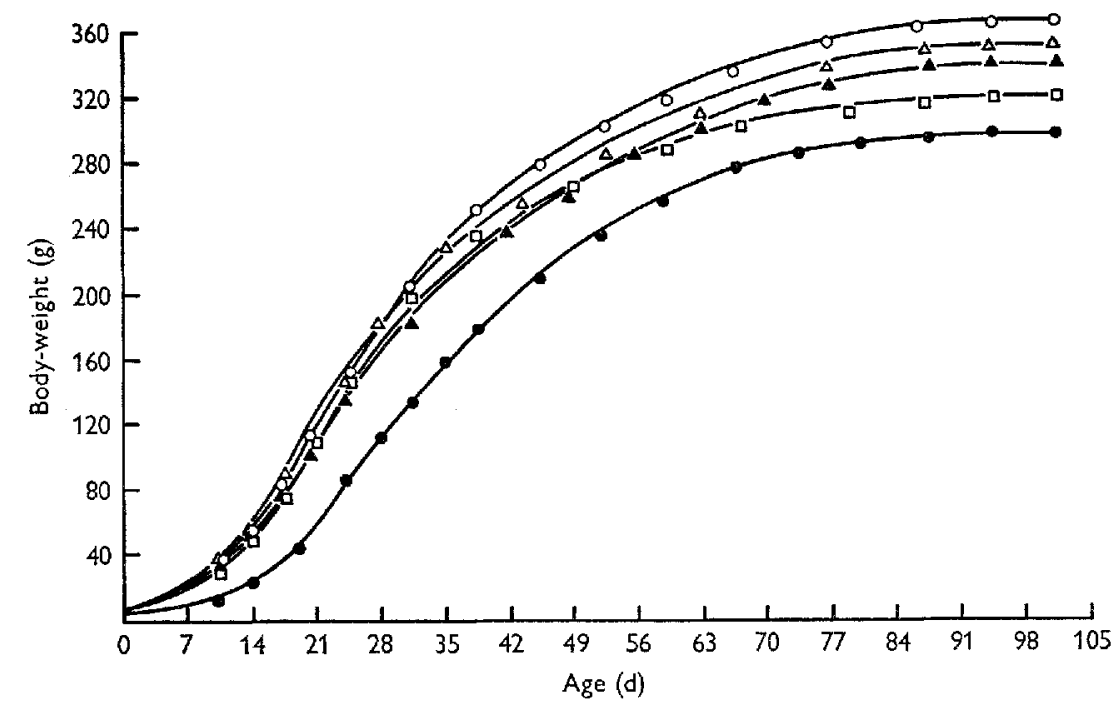

Fig- 2. Growth of male young from fourth and fifth litters born to well-nourished and malnourished rats (mean weights). $O$, group $x$, well-nourished, sixteen rats; 0 , group 2 , proteindeficient, fifteen rats; $\square$, group 3 , calorie-deficient, fifteen rats; $\Delta$, group 4 , protein-deficient then rehabilitated, fourteen rats; $\boldsymbol{\Delta}$, group 5 , calorie-deficient then rehabilitated, sixteen rats.

\section{DISCUSSION}

The results of this investigation have answered the questions posed at the outset for one species under the particular conditions imposed. Chronic deficiency of protein or of calories, starting at weaning, delayed puberty, reduced fertility and gave rise to smaller numbers in the litters. Unlimited amounts of a diet containing $9 \%$ of protein were inadequate to maintain the weight of the mothers during lactation. Their young, too, were clearly inadequately fed, for they grew to only one-half or one-third the size of the young of well-nourished mothers during the 3 weeks after birth. On the lowprotein diet, however, mothers were able to regain the weight they had lost during lactation in the course of their next pregnancy.

The animals having limited amounts of the stock diet containing $18 \%$ protein lost less weight during lactation, and they lactated better, as judged by the growth of their young, than did the animals having the low-protein diet. They might not have done so well if they had been given less food during lactation.

A more severe deprivation of protein or of calories for 9 weeks, followed by rehabilitation on unlimited amounts of the stock diet, appeared to have no permanent effect on reproductive performance. Puberty was delayed or prevented during the period of deprivation, and the vaginas of most animals did not open until rehabilitation had begun, but once the animals reached sexual maturity they were as fertile and pro- 
duced as many young as those that had been well-nourished throughout. In fact the previously calorie-deficient animals had produced more young by the time they were 60 weeks old than the well-nourished animals, even though they did not have their first litters until 4 weeks after the well-nourished controls. This was because on the whole they had more young in each of their litters. The rehabilitated animals lactated well, particularly those that had previously been calorie-deficient, and there was no carry-over of the effects of the early deficiencies.

The application of these findings to human populations must be made with caution. However, some parallels can be drawn. The earlier sexual maturation of children today as compared with 50 years ago is often attributed to improved nutrition. It is certainly associated with more rapid growth in height and weight (Tanner, I955; Cone, I961). Wilson \& Sutherland (I949) showed, among pupils attending schools in Oxfordshire, that there was a close relationship between height and weight, and age of menarche, but none of the girls could be considered to be seriously undernourished. They concluded that their results were partly accounted for by the spurt of growth that occurs around the time of puberty. There seems to be no direct evidence as to whether chronic mild undernutrition delays puberty in children or not.

It has been reported many times that the number of births goes down in times of famine, but famine in Europe has generally been associated with war, and this inevitably results in separation of the sexes. The most reliable information about the effect of a severe shortage of food on fertility is that of Smith (1947), who reported on the number of births in Rotterdam in 1944 and 1945 . Registration of vital statistics was well maintained during the German occupation and there were no major movements of population. There was a decline in birth rate, starting in June 1945 and the lowest rates were in October-December 1945 , corresponding to conceptions in the worst period of food shortage during the transport strike.

The human mother generally has only one young, so any effect of undernutrition on birth weight can only be on the weight of the individual baby. It was shown by Smith (I947) and Dean (I95I) that babies born in towns in Holland and Germany during the periods of severe food shortage in 1945 and 1946 were on the average a little smaller than those born in the same towns in times of plenty. Dean was able to compare the amounts of breast-milk produced by the mothers in a maternity hospital in Wuppertal in $1937-8$ when economic conditions were good and there were no food restrictions, and in $1945^{-6}$ when there was strict rationing and the calories available were probably less than the women needed. There was a reduction of about $25 \%$ in the amount of milk produced in the latter period. Earlier workers had demonstrated the beneficial effect on lactation of adding protein to a diet rather low in protein (Ebbs, Tisdall \& Scott, 194I) and it may be concluded that a shortage of calories or of protein reduces the amount of milk produced. On the other hand, women in areas of Africa where kwashiorkor is still a common nutritional-deficiency disease lactate extraordinarily well. These women probably suffered from some measure of protein deficiency when they were children, but they have recovered from this long ago, and although their diets contain less protein than the amount to which many European women are accustomed, they get sufficient to enable them to breast-feed their babies for a year 
or more. The protein deficiency from which they suffered early in life seems to have left no permanent mark on their reproduction or lactation.

\section{REFERENCES}

Baird, A., Widdowson, E. M. \& Cowley, J. (1971). Br. \%. Nutr. 25, 391.

Berg, B. N. (r965). F. Nutr. 87, 344.

Bruce, H. M. (1957). Stud. Fert. 9, 90.

Chow, B. F. (1964). F. Nutr. 83, 289 .

Chow, B. F. \& Lee, C.-J. (1964). F. Nutr. 82, Io.

Cone, T. E. Jr (r96r). $\mathscr{~}$. Pediat. 59, 736.

Curtiss, C. (I953). Metabolism 2, 344 .

Dean, R. F. A. (195I). Spec. Rep. Ser. med. Res. Coun. no. 275, p. 346.

Ebbs, J. H., Tisdall, F. F. \& Scott, W. A. (1941). F. Nutr. 22, 515.

Lee, C.-J. \& Chow, B. F. (1965). F. Nutr. 87, 439.

Nelson, M. M. \& Evans, H. M. (т953). \%. Nutr. 51, 7т.

Richardson, L. R., Godwin, J., Wilkes, S. \& Cannon, M. (1964). F. Nutr. 82, 257.

Seegers, W. H. (1937). Am. F. Physiol. II9, 474.

Smith, C. A. (1947). F. Pediat. 30, 229.

Stewart, R. J. C. \& Sheppard, H. G. (197ז). Br. Y. Nutr. 25, 75 .

Tanner, J. M. (1955). Growth at Adolescence. London: Oxford University Press.

Venkatachalam, P. S. \& Ramanathan, K. S. (1964). F. Nutr. 84, 38 .

Wilson, D. C. \& Sutherland, I. (1949). Br. med. F. ii, 130.

Zeman, F. J. (1967). F. Nutr. 93, 167. 